\title{
LOUIS VUITTON AS AN EXAMPLE OF THE OLD AND MODERN IN THE SAME TIME LUXURY BRAND IN THE EYES OF ITS CLIENTELE

\author{
Anastazja Magdalena Kasztalska ${ }^{1}$
}

\begin{abstract}
Louis Vuitton is a brand that has exists for a very long time and it is the perfect example to visualize how a brand can develop itself according to the needs of modern consumers. The findings of this article show that when a brand changes but saves its main features, that comes from its history, it can gain more income. Louis Vuitton can generate income through the collaboration with young artists who lead the company to a success in the market of luxury fashion. The aim of this article is to show that the Louis Vuitton Brand use the same methods since years per years and they work well perfectly by increasing the income of the brand.
\end{abstract}

UDC Classification: 005.3, 33; DOI: http://dx.doi.org/10.12955/cbup.v6.1161

Keywords: Luxury, Louis Vuitton, Brand, Marketing, Management.

\section{Origins of the Louis Vuitton}

Louis Vuitton Malletier, commonly referred to Louis Vuitton, is a French fashion house founded in 1854 by Louis Vuitton. The founder's initials are on most of the brand's products from underwear, clothing, footwear, watches, leather goods, jewellery, accessories and sunglasses. Louis Vuitton is one of the world's largest fashion houses, selling its products through independent boutiques, license shops in luxury department stores, as well as the Internet. For 6 years (2006-2012), LV was the most valuable and the most profitable luxury brand in the world. In 2012 the value of the brand was estimated at 28.4 trillion US dollars and the brand's sales revenues amounted to USD 9.4 trillion. The company is in 50 countries and has 460 stores around the world (Arati, 2009).

Louis Vuitton noticed that the wooden travel crates which were widely used were very heavy and impractical. Louis Vuitton developed a special, non-wooden canvas, thanks to which the suitcases were much lighter and more comfortable. He also changed their shape by making them all square. Thanks to the flat top surface the luggage could be stacked one on top of the other. Many craftsmen began to imitate the innovative workmanship and design. In 1857, the company took part in an international exhibition in Paris to spread their good design and advertise the brand. Vuitton in the fear of a counterfeits, he changed the color of the canvas to beige with brown stripes in 1876. The first company store was opened in London on Oxford Street in 1885. Shortly thereafter, due to the continuous imitation of the canvas, Louis created a pattern with the inscription "marque L. Vuitton déposée", which can be translated as "L. Vuitton registered trademark" (Haber, 2005).

In 1892, Louis Vuitton died, and his son, Georges Vuitton, took over management of the company. Georges Vuitton began a campaign to build an international enterprise. He appeared with his products in Chicago at the World Exhibition in 1893. Three years later, the company obtained an international patent for the use of canvas with the initials LV and a graphic sign of clovers and flowers, which were based on the trend of using Japanese and Oriental ornaments in the late Victorian era. These patents were very effective in stopping counterfeiters. Georges visited cities like New York, Philadelphia and Chicago selling his products. In 1901, the company presented its latest project, a small travel bag, which can be held inside large suitcases and can be used as a small bag for cosmetics. In 1913, the Louis Vuitton Building was opened on the avenue Champs Elysées in Paris and it was the largest store of that period, offering travel suitcases in the world. Other stores were opened in New York, Mumbai, Washington, London, Alexandria and Buenos Aires. Then, in 1930, the Keepall bag was introduced with a long, cylindrical shape. The next model was the Noé bag, which imitated its shape with a triangular sack, tied with a string from the top. This bag was originally intended for winemakers so that they could safely transport bottles of champagne. The Speedy model is yet another model that is still produced in the same shape (Guyon, 2004).

In 1936, Georges Vuitton died, and his son Gaston Louis Vuitton, took over control of the company. After the war, the Louis Vuitton company began producing small leather products, such as wallets, purses and various cases. In 1959 the company changed its monogram to make it more flexible, which allowed it to be used in small pieces of luggage and wallets. In 1966, the Papillon bag model

\footnotetext{
${ }^{1}$ Faculty of Management, Department of Marketing, University of Economics in Katowice, Poland, anastazja.kasztalska@gmail.com
} 
(cylindrical cylinder) was introduced, which is very popular today. The first stores in Japan were opened in Tokyo and Osaka in 1978 (Hirano, 2006). The company joined the America's Cup in yacht racing creating the Louis Vuitton Cup in 1983. In the same year new brand stores were created in major Asian cities such as Taipei, Taiwan and Seoul. In 1990, the company's director was Yves Carcelle, who opened the first Chinese company store location a year later in Beijing. Artistic Director in 1997 was Marc Jacobs, who designed and introduced the first line of clothing, both for women and for men. In 2002 the LV building in Tokyo was opened in the Ginza district, where Bob Wilson designed a special Christmas window design. In 2003, new stores were opened in Moscow and New Delhi in India (Ings-Chambers, 2003).

Louis Vuitton celebrated its 150th anniversary in 2004, the brand also opened of stores in New York, São Paulo, Mexico City, Cancun and in Johannesburg. In 2005, LV opened its store on the Champs Elysees in Paris, which was designed by the American architect Eric Carlson. In 2010, the brand opened its most luxurious store in London. At the beginning of 2011, Louis Vuitton hired Kim Jones for the position of director, responsible for the men's collection. Kim became a leading designer of men's clothing while working under the artistic direction of Marc Jacobs. On 17 September 2011, the company opened its first store in the Southeast Asia region, i.e. in Singapore. From September 2013. the accessory collection is run by Darren Spaziani. In $4^{\text {th }}$ November 2013 the company confirmed that Nicolas Ghesquiere will replace Marc Jacobs as the artistic director of the women's collection. The first Ghesquiere collection was presented in March 2014 in Paris. From 7 ${ }^{\text {th }}$ April 2014 Edouard Schneider became the head of the press and public relations, subordinate to Frédéric Winckler, who is the director of communication and events related to the Louis Vuitton brand (Masidlover \& Passariello, 2013).

The Louis Vuitton brand and the LV monogram are the most valuable trademarks in the world. However, their logo is one of the most often counterfeited logos in the fashion world, because of its image as a symbol of high material status. The irony is that the canvas monogram was created just to prevent counterfeiting at the very beginning of the brand's existence. In 2004 fake Louis Vuitton products accounted for as much as $18 \%$ of all counterfeit goods which were confiscated in the European Union (Kapferer \& Valette-Florence, 2016).

\section{Financial management of the Louis Vuitton brand}

Louis Vuitton has managers responsible for caring for its public opinion, and thus the brand's reputation, by skilfully covering up past mistakes. During the Second World War, Gaston collaborated with the Nazis during the German occupation of France. The book "French Saga" wrote by journalist Stephanie Bonvicini tells how members of the Vuitton family actively supported the puppet government led by Marshal Philipp Pétain, which significantly increased their wealth through commercial contacts with Germany. The Vuitton family set up a factory dedicated to the production of Pétain's glorifying goods. During its existence, this factory produced over 2,500 busts of the Marshal. Caroline Babulle, a spokeswoman for the book said: "Louis Vuitton does not question the facts contained in the book but, tries to hide them and pretend they do not exist." In response, the company spokesperson issued a statement with the content: "This is a long time ago in ancient history, and the book describes the period when the company was led by the Vuitton family, long before the current managers. Today's company is diverse, tolerant and as it should be a modern company that offers luxury goods "(Socha, 2005).

The year 1987 was the creation year of LVMH, a French company formed from the merger of Hennessy (producing cognac) and Moët \& Chandon (champagne producers Dom Pérignon, Mercier, Krug, Ruinart, Veuve Clicquot-Ponsardin) with the Louis Vuitton company. The combined enterprises created a conglomerate of luxury goods. The profits from 1988 were $49 \%$ higher than the profits from 1987, that is before the merger of companies (Hazlett, 2004).

Preventing attempts to reproduce and sell counterfeits is very important for the brand. Introduction of new product lines and adaptation of the company's classic monogram in 1999 was a successful try to stop counterfeit branded accessories. A mini monogram line was designed for small products such as keychains and key cases (Matlack, 2004). The company is actively fighting counterfeiting of its goods and employs a team of lawyers and special investigative services to detect attempts to sell or produce non-original goods around the world. The company additionally confirmed this by issuing a statement 
saying: "We have about 60 people at various levels of responsibility in the company, working fulltime, whose job is through international contact networks and connections finding and informing managers about even the smallest traces and attempts to sell, as well as the production of our fake products " (Dommer, Coleman, 2014).

Louis Vuitton strictly controls the distribution of its good. Until 1980 Vuitton products were widely sold in stores, today they are available only in original brand boutiques, exclusive shopping districts or inside luxury department stores. All LV boutiques operate independently and have their own managers and employees. The brand has its own online store on its main website, which is the only authorized online sales channel (Alcock et al., 2003).

Manual, unique and unaffected production processes are the huge value in the company. Louis Vuitton suitcases have been made by hand since the 19th century. The way of production has not changed for years - craftsmen stretch the leather on a suitcase, then they hammer in tiny nails one by one. The corners of the bag are secured by brass buckles to protect the surface of the corners, which are most vulnerable to mechanical damage. Next, the lock with the key is activated, thanks to which a customer can open all the luggage that he owns. The wooden skeleton of each suitcase is made of 30-year-old poplar, that has been allowed to dry for at least 4 years. Each suitcase has its own individual serial number, and the time it takes to complete it is 60 hours, while the bags have a minimum of 15 hours (Som, 2005).

Every year the offer of products is enlarged with limited models, not devoid of classic elements. Classic models of handbags include the Speedy and the Neverfull are each season are available in limited editions only after ordering and booking them in one of the large Louis Vuitton stores. Most of the products are sewn from traditional canvas in the colors of a brown monogram and all the goods have the serial number and title initials of the brand - LV (Cavender \& Kincade, 2014).

\section{Louis Vuitton collaboration with the artists}

Cooperation with well-known designers and the introduction of limited editions brings Louis Vuitton a lot of income. Stephen Sprouse in cooperation with Marc Jacobs, designed a limited line of Vuitton bags, which on the traditional monogram had 'Louis Vuitton' inscriptions printed sometimes with the name of the handbag model, eg Keepall or Speedy. These inscriptions looked like careless graffiti in neon colors. Some models of handbags are specially made to order, and do not have the LV monogram in the background of the graffiti (Barton, 2009).

Marc Jacobs introduced new products that expanded the company's operations. He created a bracelet in 2001, which was the first jewelry of the brand. In 2002 a collection of Tambour watches was introduced. The brand also released the Speedy line of watches in 2005 (Giacalone, 2006).

A new brand monogram and another series of limited edition products designed by well-known designers was a perfect way to make brand even more recognizable. The year 2003 was a breakthrough because Takashi Murakami introduced a new multi-colored monogram in cooperation with Marc Jacobs (the classic is a golden monogram on the background of the dark chocolate colour). The novelty consisted of incorporating the traditional monogram with new colors (as many as 33 different shades), the background color from the dark brown became white or black. Murakami also created a very well-known pattern of Cherry Blossom, in which smiling manga faces are located in the middle of cherry blossoms in a pink or yellow colour. This design was produced in a limited series, which was discontinued in June 2003 (Riot et al., 2013).

The introduction of a new canvas and accessories designed by well-known artists, addressed only to men was another huge breakout. In 2008 Louis Vuitton presented the Damier Graphite canvas that was in the classic Damier design, however, in black and gray, which gave it a very masculine, professional and elegant look. In the same year, the artist Pharrell Williams designed a series of "Blason" jewelry and sunglasses in a reflective golden color for the brand (Socha, 2008).

For the purposes of the marketing campaigns, Louis Vuitton employs many well-known musicians, models and celebrities, actresses and singers, including Keith Richards, Madonna, Jennifer Lopez, Sean Connery, Hayden Christensen and Angelina Jolie, and more recently, David Bowie. On August $2^{\text {th }} 2007$ the company announced that former the USSR leader Mikhail Gorbachev will appear in an advertising campaign with Steffi Graf, Selena Gomez and Catherine Deneuve. In addition to this, 
many rappers, especially Kanye West, Juicy $\mathbf{J}$ and Wiz Khalifa mention the company in some of their songs (Reddy, 2016).

Louis Vuitton recently decided to enter the world of television and cinema, which was very innovative and brought the company a lot of profits. The first TV commercial in the history of the brand was a huge step in the brand's marketing. A 90-second film was the first commercial TV advertisement in the history of the brand. The commercial was directed by well-known French commercial director Bruno Aveillan. The film examines the answer to the question, "Where will life take you?" The commercial's answer to the question has been translated into the 13 most used languages of the world (Soloaga \& Guerrero, 2016).

Cooperation with highly talented designers from around the world is one of the way to be the modern luxury brand. The Louis Vuitton company cooperated with many outstanding artists and designers. Takashi Murakami created a limited edition of bags with a color-changed monogram (Goh, 2012). Steven Sprous's collection referred to graffiti in neon colors, and some models of bags were even shining in the dark. The last collaboration of Marc Jacobs was projects with Yayoi Kusama, in which they created the "Infitinetly Kusama" collection, which printed tiny or very large dots on the canvas monogram. The elements of the collection are in the following colors: black with white dots, red with white dots and yellow with black dots. The collection was released in July 2012 (Socha, 2012).

\section{Methodology}

The survey is focused on people selected by the interviewer that represent interesting and testable qualities. The survey omits people that are not interested in what is being studied. Every respondent had their own, individual opinion about luxury goods. Individuals who for various reasons are not interested in the luxury industry, were excluded from the study because they do not have relevant experience and a clear opinion about exclusive goods and luxury markets.

The survey was sent by email to people who are actively participating in the life of the luxury industry, as well as fans of it. 134 people participated in the survey. The survey was conducted in period of February 2018 to March 2018. Respondents had a very high degree of freedom of expression because they could modify the questions and add their own observations and comments. Subjects were men and women, diverse in age, as the youngest tested person was 18 years old and the oldest 76 . Age and gender had little significance as a major determinant. The main factor was the wealth of a person who could afford to be an owner of luxury goods.

\begin{tabular}{|c|c|}
\hline Table 1: The reasons of buying luxury products of Louis Vuitton. \\
\hline Why do you buy luxury products of Louis Vuitton? & Answers in \% \\
\hline Quality of materials & $26 \%$ \\
\hline Craftsmanship & $10 \%$ \\
\hline Increase self-esteem & $2 \%$ \\
\hline Art mastery & $4 \%$ \\
\hline Image of the brand? & $27 \%$ \\
\hline Emotions connected with buying luxury products. & $31 \%$ \\
\hline Source: Author based upon data from the survey. \\
\hline
\end{tabular}

\section{Conclusion}

Luxury brands have to change and develop to become modern brands. Louis Vuitton belongs to such kind of brands. The company is able to use its potential to develop its position on the market, that is the result of a very long and turbulent history. Louis Vuitton is also able to use with success the process of manual production of its products that has been developed for centuries. Most importantly, Louis Vuitton cooperates with young, very talented designers who give modernity to the classic products of the brand. The company actively cooperates with celebrities from around the world who are successful and powerful in the world of music and film and who are icons for many young people. Thanks to this the brand gains new loyal consumers. A luxury brand should not only exist, it must still change and redefine well-known concepts, while respecting its history and the way of making its products. There are very few luxury brands in the world that can combine their past and history with the future, new trends and growing expectations of their clients. The Louis Vuitton brand has huge potential, thanks to drawing on its history while looking to the future. 


\section{References}

Alcock, L., Chen, P., Ch'ng, H. M., Hodson, S., \& al, e. (2003). Counterfeiting: Tricks and trends. Journal of Brand Management, 11(2), 133-136.

Arati, M. C. (2009, Dec 05). Visionary spirit of louis vuitton. McClatchy - Tribune Business News

Barton, K. A. (2009). Back to the beginning: A revival of a 1913 argument for intellectual property protection for fashion design. Journal of Corporation Law, 35(2), 425-448.

Cavender, R., \& Kincade, D. H. (2014). Management of a luxury brand: Dimensions and sub-variables from a case study of LVMH. Journal of Fashion Marketing and Management, 18(2), 231-248.

Dommer, S., \& Coleman, N. (2014). My louis vuitton bag from ebay is definitely genuine: Closing the self-discrepancy gap through self-deception with brands. Advances in Consumer Research, 42, 458.

Giacalone, J. A. (2006). THE MARKET FOR LUXURY GOODS: THE CASE OF THE COMITÉ COLBERT1. Southern Business Review, 32(1), 33-40.

Goh, D. (2012, Jul 14). Louis vuitton is hot for spots. The Business Times.

Guyon, J. (2004, Sep 06). THE MAGIC TOUCH. Fortune, 150, 229-236.

Haber, H. (2005). VUITTON GARDEN: A MAZE THROUGH HISTORY. WWD, 189(103), 14.

Hazlett, C. (2004). LVMH: Luxury's international name. Retail Traffic, 33(5), 64.

Hirano, K. (2006). VUITTON SEES FURTHER GROWTH IN JAPAN. WWD, 191(123), 3.

Ings-Chambers, E. (2003, May 10). A brand new passage to india: Edwina ings-chambers reports on louis vuitton's latest move into the asian luxury goods market. Financial Times

Kapferer, J., \& Valette-Florence, P. (2016). Beyond rarity: The paths of luxury desire. how luxury brands grow yet remain desirable. The Journal of Product and Brand Management, 25(2), 120-133.

Masidlover, N., \& Passariello, C. (2013, Nov 04). Louis vuitton appoints ghesquière as creative director; designer replaces marc jacobs as fashion house seeks to bolster reputation. Wall Street Journal

Matlack, C., \& With Diane Brady in New York, Robert Berner in Chicago, Rachel Tiplady in Paris, and Hiroko Tashiro,in Tokyo. (2004, Mar 22). The vuitton money machine; inside the world's biggest, most profitable luxury brand. Business Week, , 48-102.

Reddy, S. (2016, Jan 14). Celebrities impress at louis vuitton's UNICEF gala in los angeles panache]. The Economic Times Riot, E., Chamaret, C., \& Rigaud, E. (2013). Murakami on the bag: Louis vuitton's decommoditization strategy. International Journal of Retail \& Distribution Management, 41(11), 919-939.

Socha, M. (2005). KING LOUIS. WWD, 190(76), 1.

Socha, M. (2008). PHARRELL WILLIAMS TO UNVEIL LOUIS VUITTON JEWELRY LINE. Wwd, 195(14), 14.

Socha, M. (2012). Vuitton gets artsy again. Wwd, 203(107), 1-n/a.

Soloaga, P. D., \& Guerrero, L. G. (2016). Fashion films as a new communication format to build fashion brands. Comunicación y Sociedad, 29(2), 45-61.

Som, A. (2005, Winter). Personal touch that built an empire of style and luxury. European Business Forum, , 69-71. 